\title{
Effects of sugars on the absorption of copper from the small intestine of rat
}

\author{
Masaya Ohara, Bernard Peiris*, Masanori Ikuzawa and Shoji Uesaka \\ (Loboratory of Zootechnical Science, Faculty of Agriculture, Kyoto Universite)
}

(Received for Publication on June 12, 1968)

Copper as an important nutrient in the feeding of livestock has been widely acclaimed. Anemia in cattle, pigs and sheep, rickets in young calves, ataxia or 'swayback' in lambs, fibrosis of the myocardium in cattle, cardiac hypertrophy in pigs and scouring in calves, are accompanied with copper deficiency. These diseases have been shown to respond to the administration of copper. Toxicity of copper has also been reported ${ }^{13)}$. Little is known of the minimum requirements of copper for growth and production for different species, and about the factors influencing the absorption of copper at the mucosal level of the intestine. Several dietary factors have also shown to influence the intakes and utilization of copper. Knowledge on the mechanism of absorption, its transport and metabolism is limited.

Previous communications from this laboratory, work has been presented on the effects of amino acids ${ }^{6}$, and of fatty acids $^{7}$, on the absorption of copper from the small intestine of the rat. In this paper the effects of some monosaccharides and disaccharides on the absorption of copper from the small intestine of the rat are described.

\section{Methods and Materials}

Male and female rats weighing 200 to $300 \mathrm{~g}$ used in this experiment were of the Wistar strain. The rats were raised and maintained on a commercial pellet and tap water ad libitum, and fasted for 24 hours prior to the experiments. The animals were anaesthetized by the subcutaneous administration of nembutal, $0.08 \mathrm{ml}$ per $100 \mathrm{~g}$ body weight. The abdomen was

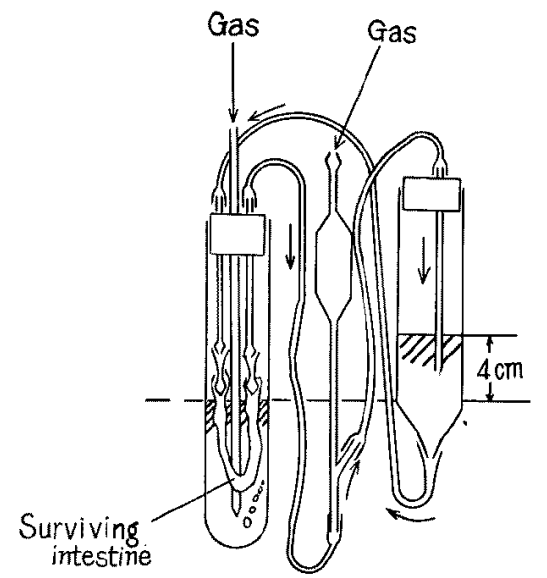

Fig. 1. In vitro intestinal perfusion apparatus

\footnotetext{
* Japanese Goverment Scholar from the Department of Agriculture Ceylon.
} 
The intestinal segments were washed with physiological saline solution to get rid of the intestinal contents, blotted gently and then used for the experiment. For each experiment seven segments were used from an animal. Seven sets of apparatus were set up of which three were controls. The intestinal perfusion apparatus developed in this laboratory and used for this experiment is shown in Fig. 10,11].

The mucosal and serosal solutions were made up of KREBS RINGER bicarbonate pH 7.4, $0.5 \%$ polyethylene glycol 4,000 and $2.5 \mu \mathrm{g} / \mathrm{m} l$ copper $\left(\mathrm{CuCl}_{2} \cdot 2 \mathrm{H}_{2} \mathrm{O}\right)$. In addition, the mucosal solution contained the sugar under study. The monosaccharide, i.e. glucose, galactose, sorbose and fructose, and the disaccharide, i.e. lactose and sucrose at different concentrations, were tested for their effects on copper absorption. The apparatus containing $50 \mathrm{~m} l$ each of the mucosal and serosal solutions were placed in a water bath at $37.4^{\circ} \mathrm{C}$. The serosal solution was oxygenated prior to the fixing of the intestinal segments. During one hour of circulation adequate aeration with $95 \% \quad \mathrm{O}_{2}$ and $5 \% \quad \mathrm{CO}_{3}$ gas mixture was provided. After an hour circulation, the solution remaining in the intestine and the circulatory system was carefully emptied into the mucosal tube. Fifteen $\mathrm{m} l$ of this solution was taken and diluted with $15 \mathrm{~m} l$ $2 \mathrm{~N} \mathrm{HCl}$ and centrifuged for 10 minutes at 3,000 r.p.m. Final analysis of copper was done using the atomic absorption flame spectrometer (Nippon Jarrel Ash). The average of the control experiments was taken as 100 and this index was used for all calculations.

\section{Results}

Figure 2 indicates the effects of $0,0.2 \%, 2.5 \%, 5.0 \%, 7.5 \%$ and $10.0 \%$ glucose. At $2.5 \%$ concentration of glucose there was an enhanced absorption rate of copper. It was also seen that with the increase in the concentration of glucose above $5.0 \%$ there was a gradual decline in the rate of absorption. The lowest was seen at $10.0 \%$ concentration. Thus it was evident that a concentration above $5.0 \%$ had a detrimental effect on the rate of absorption of copper.

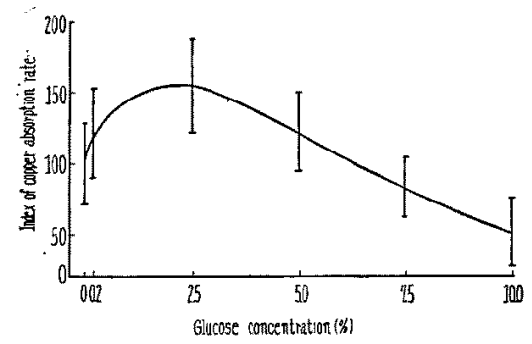

Fig. 2. Effect of different concentrations of glucose on copper absorption

Table 1 shows the data on the effect of galactose on the absorption of copper. Galactose at $0.2 \%$ concentration showed a slight enhancing effect but at $2.5 \%$ there was no enhancement of copper absorption. But with a high concentration (10\% galactose) it showed an adverse effect which was comparable to that of glucose at the same concentration.

The data presented in Tables $2 \& 3$ show the effects of the two ketohexose, fructose and sorbose, on copper absorption. In the case of fructose it was seen that $0.2 \%$ and $2.5 \%$ did not have any beneficial effect when compared to the control. At $0.2 \%$ level there was a suppression of the absorption rate of copper. With the increase in the concentration of 
Ohara - Peiris - Ikuzawa - Uesaka

Table 1. Effect of galactose on $\mathrm{Cu}^{++}$absorption

\begin{tabular}{c|c|c}
\hline $\begin{array}{c}\text { Galactose concentration } \\
\%\end{array}$ & $\begin{array}{c}\text { No. of intestinal } \\
\text { segments }\end{array}$ & $\begin{array}{c}\text { Index of copper } \\
\text { absorption rate* }\end{array}$ \\
\hline 0 & 7 & $100.0 \pm 22.3$ \\
0.2 & 4 & $119.9 \pm 31.2$ \\
2.5 & 7 & $108.7 \pm 25.1$ \\
10.0 & 4 & $44.5 \pm 14.3$ \\
\hline
\end{tabular}

* Meant \pm tandard deviation.

Table 2. Effect of fructose on $\mathrm{Cu}^{++}$absorption

\begin{tabular}{c|c|c}
\hline $\begin{array}{c}\text { Fructose concentration } \\
\%\end{array}$ & $\begin{array}{c}\text { No. of intestinal } \\
\text { segments }\end{array}$ & $\begin{array}{c}\text { Index of copper } \\
\text { absorption rate* }\end{array}$ \\
\hline 0 & 7 & $100.0 \pm 7.9$ \\
0.2 & 3 & $75.8 \pm 36.6$ \\
2.5 & 8 & $94.9 \pm 27.6$ \\
10.0 & 4 & $23.2 \pm 3.9$ \\
\hline
\end{tabular}

* Mean \pm Standard deviation.

Table 3. Effect of sorbose on $\mathrm{Cu}^{++}$absorption

\begin{tabular}{c|c|c}
\hline Sorbose concentration & $\begin{array}{c}\text { No. of intestinal } \\
\text { segments }\end{array}$ & $\begin{array}{c}\text { Index of copper } \\
\text { absorption rate* }\end{array}$ \\
\hline 0 & 9 & $100.0 \pm 38.4$ \\
0.2 & 7 & $84.3 \pm 39.3$ \\
1.0 & 6 & $99.2 \pm 28.0$ \\
\hline
\end{tabular}

* Mean \pm Standard deviation.

Table 4. Effect of sucrose on $\mathrm{Cu}^{++}$absorption

\begin{tabular}{c|c|c}
\hline Sucrose concentration & $\begin{array}{c}\text { No. of intestinal } \\
\text { segments }\end{array}$ & $\begin{array}{c}\text { Index of copper } \\
\text { absorption rate* }\end{array}$ \\
\hline 0 & 3 & $100.0 \pm 24.1$ \\
1.0 & 3 & $89.0 \pm 7.9$ \\
10.0 & 3 & $55.4 \pm 4.0$ \\
\hline
\end{tabular}

* Mean \pm Standard deviation.

Table 5. Effect of lactose on $\mathrm{Cu}^{++}$absorption

\begin{tabular}{c|c|c}
\hline Lactose concentration & $\begin{array}{c}\text { No. of intestinal } \\
\text { segments }\end{array}$ & $\begin{array}{c}\text { Index of copper } \\
\text { absorption rate* }\end{array}$ \\
\hline 0 & 5 & $100.0 \pm 19.1$ \\
1.0 & 3 & $84.3 \pm 16.3$ \\
10.0 & 7 & $80.4 \pm 2.6$ \\
\hline
\end{tabular}

* Mean \pm Standard deviation. 


\section{Effects of sugars on copper absorption}

opened and segments approximately $8 \mathrm{~cm}$ in length were excised from the jejunum and ileum. fructose to $10.0 \%$, the index of copper absorption rate dropped to a mean of 23.2 , showing that the ketohexose fructose behaved similarly to the aldohexoses at high concentrations.

Sorbose did not show any effect on copper absorption either at $0.2 \%$ or $1.0 \%$ concentration levels, and there was no significant difference between $0.2 \%$ and $1.0 \%$ sorbose.

Tables 4 and 5 give the data on the effects of lactose and sucrose on copper absorption. Lactose at $1.0 \%$ and $10.0 \%$ concentrations showed a decreased absorption of copper but there was no significant difference between the control and the $10.0 \%$ level of concentration.

In the case of sucrose at $10.0 \%$ a low rate of absorption was observed, $(\mathrm{p}<0.05)$ compared with the control. Sucrose and lactose at $1.0 \%$ concentration did not remarkably alter the gastrointestinal absorption of copper.

\section{Discussion.}

Glucose forms the structural unit of important polysaccharides, while galactose is a component of lactose and many polysaccharides. The effects of these two sugars, and ketohexose, fructose and sorbose, were tested among the monosacharides, and sucrose, and lactose among the disaccharides. Lactose occurs in the milk of mammals and gives a mixture of glucose and galactose on hydrolysis by acid or the enzyme in the small intestine. Sucrose on the other hand is found in all photosynthetic plants and is an important carbohydrate in the natural feed of animals. On hydrolysis by acid or the enzyme of the intestine it gives a mixture of glucose and fructose. These sugars which are of great biochemical interest were studied.

By comparison of the six sugars on the influence on copper absorption, it was demonstrated that only glucose had a beneficial effect on copper absorption by rat intestine studied in ' in vitro'. From the data presented in Figure 2, it may be said that a concentration below $5.0 \%$ enhanced copper absorption. The enhanced action of glucose on copper absorption may be attributed to the fact that energy from glucose was used up for the active transport of copper. Earlier papers have presented evidence that copper absorption is dependent on the respiratory mechanism of the mucosa ${ }^{11)}$. Glucose as an effective substrate for ion transport in toad bladder $^{4)}$ and rabbit ileum ${ }^{8,9}$ has been reported. The observation that glucose has an enhancing effect on copper absorption from the gastrointestinal tract of the rat is a new finding. Though galactose did not show such a favourable influence on copper absorption as glucose, at $0.2 \%$ it showed a slight enhancement. The two aldohexoses at a high concentration of $10.0 \%$ had an adverse effect on the absorption of copper, while at a low concentration it was apparent that glucose was a good substrate for copper absorption than galactose. It has been reported that galactose is absorbed more rapidly than glucose ${ }^{2\rangle}$ and also that glucose is metabolised $\mathrm{im}$. mediately after absorption while galactose to be metabolised at a very slow rate ${ }^{(2)}$. In the present experiment it showed that galactose had a lower enhancing effect than glucose which may be due to the fact that galactose was metabolised more slowly compared to glucose and thus less energy available for the absorption of copper.

The two ketohexoses, fructose and sorbose, showed no beneficial effect on copper absorption. In contrast to glucose sorbose is reported to be passively transported ${ }^{37}$ and that only sugars with the $\mathrm{OH}$ radical attached to the second carbon atom to be actively transported ${ }^{5}$. Here we can assume that a lower amount of ketohexose is absorbed from the intestine than in the case of aldohexoses. Hence it may be said that energy from ketohexoses is not available 
ior copper absorption.

Definitive statements regarding the action of these two groups of sugars on the absorption of copper cannot be given from the present observations. All sugars tested showed a detrimental effect upon copper absorption at $10.0 \%$ concentration. This may be explained as to the formation of sugar chelates with the metal ion ${ }^{1,4,8,93}$, and it may also be due to the change in the osmotic pressure in the mucosal cells bringing about a physiological disturbance at the mucosal level at a high concentration of sugar.

\section{Summary}

1. The effects of sugars on the absorption of copper from the gastrointestinal tract of the rat was studied, in 'in vitro' using the intestinal perfusion apparatus.

2. A concentration of $2.5 \%$ glucose enhanced the absorption of copper. A concentration above $5.0 \%$ glucose demonstrated a low rate of copper absorption.

3. The aldohexose showed a stimulating effect when compared with the ketohexose.

4. All sugars tested showed a decline on the rate of copper absorption at $10.0 \%$ concentration.

\section{References}

1) Charley, P.J., C.F. Stitt, B. Sarkar and P. Saltman (1963) Biochim. Biophys. Acta., 69:319-320.

2) CoRi, C.F. (1925) J. Biol. Chem., 66:691.

3) Hagihara, H., S. Akedo and M. Suda (1963) Protein - Nucleic Acid - Enzyme, 8 (8): 438-452.

4) Maffly, R.H. and I.S. Edelman (1963) J. Gen. Physiol., 46 (2): 733-752.

5) NAKaO, M. (1966) Gendai no Seibutsugaku, (2): 190 Iwanami Shoten, Tokyo.

6) Ohara, M., S. Uesaka, N. Kobayashi and T. Yamashita (1967) Bull. Res. Inst. Food Sci., Kyoto Univ., 30: 5-17.

7) Ohara, M., S. Uesaka and M. IkUzawa (1966) Nicchikukai Kansaishibuho 45: 31-32.

8) Schultz, S.G. and R. Zalusky (1963-64) J. Gen. Physiol., 47 (1): 567-583.

9) Schultz, S.G. and R. Zalusky (1964) J. Gen. Physiol., 47 (2): 1043-1059.

10) Uesaka, S. and M. Ohara (1964) Bull. Res. Inst. Food Sci., Kyoto Univ., 27: 40-51.

11) Uesaka, S. and M. Ohara (1966) Bull. Res. Inst. Food Sci., Kyoto Univ., 29: 33-48.

12) Uı, N. and S. Takasugi (1966) Gendai no Seibutsugaku, (7): 60 Iwanami Shoten, Tokyo.

13) Underwood, E.J. (1962) Trace Elements in Human and Animal Nutrition, 2 ed. 48-93, Academic Press Inc. New York and London. 


\section{ラットにおける銅の腸管吸収に及ぼす糖の影響}

\section{小原正哉・バーナードピーリス・生沢政則・上坂章次}

\section{(京都大学農学部)}

本報告は，ラット小腸に打ける $\mathrm{Cu}^{++}$吸收に及济与影

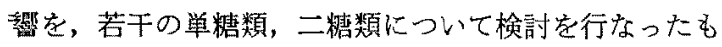
のである. 実験方法は，ウィスター采ラット小腸（十二 指腸を除くによる in vitro 腸管潅流法を用心た。供 試腸管は, 体重 $200 \sim 300 \mathrm{~g}$ のラットを約 24 時間絶食 後，麻配し開腹手術により摘出したもので，腸管带は約 $.8 \mathrm{~cm}$, 腸管膨圧は， $4 \mathrm{~cm} \mathrm{H} 2 \mathrm{O}$, 還流流速性, $15 \mathrm{ml} / \mathrm{min}$ である。供試溶液は， $\mathrm{Cu}^{++} 25 \mu \mathrm{g} / \mathrm{m} l$ と $0.5 \% \mathrm{PEG}$ （容量指標物質）とを含む KRB 溶液を基調液とし, こ れに種々の濃度の各種の糖を添加した。吸収の程度は， 粘膜側の $\mathrm{Cu}^{++}$量隇少率 (吸収率) 対照区 (糖無添加) のそれを 100 とする指数で表わした．結果は，(1) グル ニース $0.2 \%, 2.5 \%, 5.0 \%, 7.5 \%, 10.0 \%$ 添加した 場合の $\mathrm{Cu}^{++}$吸収は，それぞれ平均 $120.5 ， 154.3$, $121.7,82.6,51.2$ であった. (2) ガラクトース $0.2 \%$, $2.5 \%, 10.0 \%$ 各添加区の平均 $\mathrm{Cu}^{++}$吸收は，去れぞれ 119.9，108.7，44.5宗した.（3）ケトース型の糖であ るフラクトースは，0.2\%, 2.5\%, $10.0 \%$ の添加によ りそれれぞれ平均 $75.8,94.9,23.2 の \mathrm{Cu}^{++}$吸収宗
した. またソルボースの場合は， $0.2 \% ， 1.0 \%$ の添加 で，それぞれ.84.3，99.2であった（4) 二糖類である ラクトースの場合は, $1.0 \%, 10.0 \%$ 添加で，平均 $\mathrm{Cu}^{++}$ 吸收注，それぞれ 84.3，80.4，シニークロース $1.0 \%$, 10.0\% 添加で，それを゙れ 89.0，55.4 を示した。

以上の結果から，グルュース $5 \%$ まで，およびガラタ トース $0.2 \%$ で添加は, $\mathrm{Cu}^{++}$吸収を, 促進せしめて いるが, この事は, これらの糖が, $\mathrm{Cu}^{++}$の能動榆送の エネルギー源として利用されていることを西るるのて はないかと思孙れる。その他の糖では，添加によって $\mathrm{Cu}^{++}$吸收の促進はみられていない。こ机は，ダルコ一 スに比べて。これら糖自体の吸収され，そして利用さ れる速度が著しく小さいことによるものではないだろう

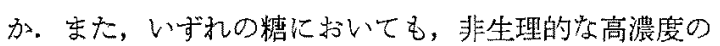
添加は， $\mathrm{Cu}^{++}$吸収に対して，抑制的に墈らくと思われ るが，これは， $\mathrm{Cu}^{++}$と糖との錯塩形成によるものに加 えて, 非生理的条件下に劣ける腸粘膜細胞の活性低下に よるむのではないかと考えられる。 